\title{
Tingkat Kepuasan Mahasiswa Terhadap Kualitas Pelayanan Angkot di Kota Medan
}

\author{
Reynaldo ${ }^{1}$
}

\begin{abstract}
In general, urban transportation experiences similar problem, which is the low level of public transport occupancy. There are numerous factors that can cause such condition, of which can be summarized in the form of service quality shortcoming. Service quality of such public facility is measured and evaluated based on user experience, and planners utilize it to plan for future improvements. Importance-Performance Analysis is used in this research to identify aspects of service that are expected to be on top of enhancement priority list. Based on 159 students' responses, it was found that six service criterias are in high-priority-quadrant. These are crowding, sitting comfort, hygiene, driver behavior, driver cleanliness, and security. Specifically, driver behavior aspect is regarded as highly prioritized, whereas on the contrary angkot fare and operating time are considered good enough and thus placed on low-priority list.
\end{abstract}

Kata kunci: kualitas pelayanan, angkot, mahasiswa, importance-performance analysis

\section{Pendahuluan}

Transportasi perkotaan di berbagai tempat pada umumnya mengalami permasalahan yang mirip, yaitu tingkat pengguna angkutan umum yang rendah. Perjalanan harian dalam perkotaan mayoritas dilakukan dengan menggunakan kendaraan pribadi, baik sepeda motor maupun mobil pribadi. Faktor penyebab rendahnya okupansi angkutan umum dapat berupa banyak hal, seperti minimnya ketersediaan rute yang luas, tarif angkutan yang terlalu mahal, kenyamanan berkendara yang rendah, waktu perjalanan yang relatif lebih tinggi, dan lain sebagainya. Sebagian penyederhanaan, faktor-faktor ini dapat dinyatakan dengan terminologi kualitas pelayanan (service quality). Beberapa jenis aspek pelayanan seperti keterandalan dan frekuensi kedatangan memiliki efektifitas yang tinggi dalam menarik pengemudi mobil berpindah ke transportasi publik (Redman, 2013).

Kualitas pelayanan secara umum dinyatakan sebagai rekapitulasi persepsi pelanggan terhadap pengalaman pelayanan. Pengguna layanan membentuk ekspektasi terhadap pelayanan berdasarkan berbagai sumber seperti pengalaman masa lalu, kabar dari mulut ke mulut, dan periklanan. Pada dasarnya pelanggan membandingkan layanan yang dirasakan dengan layanan yang diharapkan (ekspektasi). Jika layanan yang dialami dianggap berada di bawah layanan yang diharapkan, pelanggan menyatakan ketidakpuasan dan demikian sebaliknya. (Martilla, 1977) Selain hal fisik seperti ketersediaan bangku yang nyaman, pendingin kendaraan, maupun halte yang nyaman, aspek perilaku sosial seperti keramahan supir dan kebersihan supir juga menjadi penentu kepuasan pengguna angkutan umum. (dell'Olio, 2011).

Kota Medan memiliki pilihan angkutan umum yang sangat minim, tetapi di sisi lain sangat luas jangkauannya. Angkutan umum formal yang tersedia di kota Medan hanya berupa angkot dengan rute yang tertentu tetapi tidak berjadwal. Sementara itu, becak motor dianggap

\footnotetext{
${ }^{1}$ Staf Pengajar Teknik Sipil Universitas Katolik Santo Thomas e-mail: siahaan.reynaldo@gmail.com
} 
sebagai angkutan umum informal. Meskipun pilihan hanya berupa angkot, rute yang dilayani oleh angkot di kota Medan cukup luas, dan pengguna dapat mencapai sebagian besar wilayah di kota Medan dengan menggunakan angkot.

\section{Tujuan}

Penelitian ini bertujuan untuk mengukur dengan skala kuantitatif tingkat kepuasan mahasiswa terhadap kualitas pelayanan angkot di Medan. Tingkat kepuasan dinyatakan dalam skala penilaian yang mudah dipahami, yakni skala Likert. Lebih lanjut, dalam upaya meningkatkan tingkat kepuasan ini di masa akan datang, dilakukan identifikasi terhadap aspek pelayanan yang memerlukan lebih banyak perhatian, ataupun yang perlu diprioritaskan berdasarkan persepsi mahasiswa sebagai pengguna.

\section{Tinjauan Pustaka}

\section{Indeks Kepuasan Konsumen}

Istilah Customer Satisfaction Index (CSI) muncul di bidang marketing untuk mengukur nilai kepuasan konsumen. Beragam metoda untuk mengukur nilai kepuasan konsumen telah dikembangkan selama bertahun-tahun. Namun, metoda yang paling populer dikembangkan oleh Parasuraman (1985) dan dikenal dengan nama metoda ServQual. Konsep yang dikemukakan adalah nilai kepuasan konsumen merupakan fungsi dari ekspektasi dan realisasi yang dirasakan.

Konsumen diminta untuk menyatakan ekspektasi mereka terhadap sejumlah kriteria pelayanan dalam sebuah skala berjenis Likert. Kemudian, untuk kriteria pelayanan yang sama, konsumen diminta untuk memberikan nilai akan realisasi yang mereka rasakan, juga dalam skala berjenis Likert. Nilai kepentingan dijadikan faktor pembobotan (weight factor) terhadap rata-rata nilai kepuasan terhadap realisasi yang dirasakan responden. Secara umum CSI dapat dihitung dengan menggunakan formula berikut ini (Eboli \& Mazula, 2009).

$$
C S J=\sum_{i=1}^{n}\left[\bar{s}_{k}+w_{k}\right]
$$

dimana : $\quad \bar{S}_{k}$ adalah rerata nilai kepuasan untuk kriteria pelayanan $k$;

$W_{k}$ adalah besaran bobot tingkat kepentingan kriteria pelayanan $k$

$W_{k}$ dinyatakan sebagai rasio antara rerata nilai kepentingan yang dinyatakan terhadap kriteria pelayanan $k$ terhadap akumulasi rerata nilai kepentingan seluruh kriteria.

$$
W_{k}=\frac{\bar{J}_{i k}}{\sum_{i=1}^{N} \bar{l}_{k}}
$$

dimana $\bar{l}_{k}$ adalah rerata nilai kepentingan dinyatakan terhadap kriteria pelayanan $k$.

\section{Importance-Performance Analysis}

Teknik IPA mengkombinasikan 2 (dua) jenis ukuran yang dimiliki pelanggan, yakni tingkat kepentingan (importance) dan tingkat penilaian terhadap kinerja (performance). Teknik ini dikemukakan oleh Martilla \& James pada tahun 1977 dalam bidang marketing, tepatnya untuk mengukur dan mengevaluasi penerimaan konsumer (consumer acceptance) terhadap program marketing yang baru diimplementasikan. Keduanya memiliki konsep bahwa 
kepuasan konsumen merupakan fungsi dari persepsi konsumen terhadap pentingnya suatu fitur dengan persepsi konsumen terhadap kinerja fitur tersebut dalam praktiknya.

Visualisasi data dalam teknik ini dilakukan dengan plotting kriteria ke dalam empat kategori atau kuadran. Salah satu sumbu dikategorikan sebagai tingkat kepentingan, sedangkan sumbu lainnya merupakan penilaian kepuasan. Keempat kuadran dan pengertian masing-masing kuadran secara visual dapat dilihat pada gambar berikut ini (Sever, 2015). Kuadran 4 merupakan bagian yang sangat perlu difokuskan karena memiliki tingkat kepentingan yang sangat tinggi tetapi kinerjanya sangat buruk.

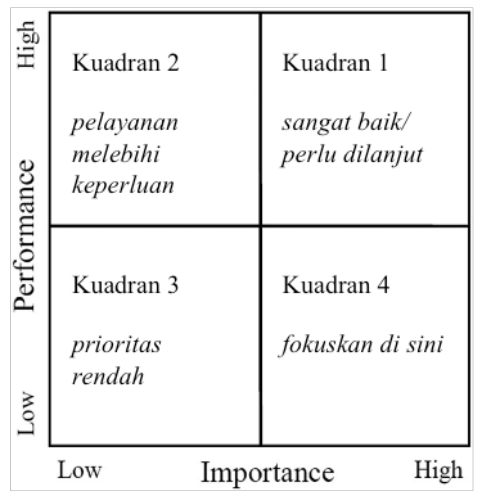

Gambar 1 Pembagian Kuadran Dalam Analisa IPA

Setiawan (2005) dan Idris (2009) mempergunakan teknik yang sama dan memperoleh hasil penilaian yang hampir serupa, dimana ketepatan jadwal menjadi aspek yang perlu diprioritaskan untuk ditingkatkan.

\section{Metodologi}

Pengumpulan data primer dilakukan dengan metoda wawancara mempergunakan kuesioner. Responden mahasiswa diminta untuk menjawab sejumlah pertanyaan yang terbagi atas tiga bagian. Bagian pertama berisi pertanyaan mengenai kondisi sosial-ekonomi responden mahasiswa. Bagian kedua berisi isian berskala mengenai persepsi responden mahasiswa terhadap tingkat kepentingan beberapa faktor pelayanan yang disajikan. Sementara itu, bagian ketiga berisi isian berskala mengenai persepsi kepuasan mereka terhadap beberapa faktor pelayanan angkutan umum pada bagian kedua.

Persepsi kepentingan dan kepuasan disajikan dalam skala Likert untuk mengukur tingkatan terhadap masing-masing faktor pelayanan yang diukur dalam kuesioner tersebut. Skala Likert yang dipergunakan dimulai dari angka 0 hingga angka 10, dimana angka 0 bermakna sangat tidak puas/sangat tidak penting serta angka 10 bermakna sangat puas/sangat penting.

\section{Hasil dan Pembahasan}

\section{Distribusi Responden}

Tabel 1 menunjukkan rekapitulasi statistik responden yang telah diwawancarai. Dari 159 orang responden, $61(38,4 \%)$ di antaranya merupakan laki-laki, dan 98 merupakan perempuan. Sebagian besar $(73 \%)$ responden mahasiswa merupakan pengguna angkot yang tidak rutin, yakni yang frekuensi penggunaannya tidak setiap hari. Sebaran usia responden mahasiswa didominasi oleh kelompok usia lebih dari 22 tahun, yakni sebanyak 53 orang 
(33,3\%). Jumlah mahasiswa berusia 19 tahun merupakan kelompok terbanyak kedua, yakni $40(25,2 \%)$ responden. Sedangkan kelompok usia 17 tahun adalah yang memiliki jumlah responden tersedikit, yakni sebanyak 4 orang (2,5\%). Mayoritas kelompok responden (54 orang) memiliki besaran uang bulanan sekitar Rp 500.000. hingga Rp 750.000. Sementara itu, hanya 18 orang $(11,3 \%)$ responden yang menerima uang lebih dari Rp 1.500 .000 setiap bulannya. Di antara para responden, sebagian besar (79 orang) tidak memiliki kendaraan pribadi, sebanyak 71 orang $(44,7 \%)$ memiliki sepeda motor, dan hanya 9 orang $(5,7 \%)$ yang memiliki mobil pribadi.

Tabel 1. Rekapitulasi Statistik Responden

\begin{tabular}{|c|c|c|}
\hline Kategori & Jumlah & \\
\hline \multicolumn{3}{|l|}{ Tipe Pengguna } \\
\hline Tidak Rutin & 116 & $73,0 \%$ \\
\hline Rutin & 43 & $27,0 \%$ \\
\hline \multicolumn{3}{|l|}{ Kelompok Usia } \\
\hline 17 & 4 & $2,5 \%$ \\
\hline 18 & 15 & $9,4 \%$ \\
\hline 19 & 40 & $25,2 \%$ \\
\hline 20 & 22 & $13,8 \%$ \\
\hline 21 & 25 & $15,7 \%$ \\
\hline$>22$ & 53 & $33,3 \%$ \\
\hline \multicolumn{3}{|l|}{ Gender } \\
\hline Laki & 61 & $38,4 \%$ \\
\hline Perempuan & 98 & $61,6 \%$ \\
\hline \multicolumn{3}{|l|}{ Kepemilikan Kendaraan Pribadi } \\
\hline Memiliki Sepeda Motor & 71 & $44,7 \%$ \\
\hline Memiliki Mobil & 9 & $5,7 \%$ \\
\hline Tidak Memiliki Angkutan Pribadi & 79 & $49,7 \%$ \\
\hline \multicolumn{3}{|l|}{ Besar Uang Bulanan } \\
\hline kurang dari 500ribu & 28 & $17,6 \%$ \\
\hline 500ribu - 750ribu & 54 & $34,0 \%$ \\
\hline 750ribu - 1juta & 35 & $22,0 \%$ \\
\hline 1juta $-1,5$ juta & 24 & $15,1 \%$ \\
\hline lebih dari 1,5juta & 18 & $11,3 \%$ \\
\hline \multicolumn{3}{|l|}{ Jenis Perjalanan Dengan Angkot } \\
\hline Dari / Ke Kampus & 80 & $50,3 \%$ \\
\hline Berbelanja & 29 & $18,2 \%$ \\
\hline Rekreasi & 15 & $9,4 \%$ \\
\hline Lainnya & 35 & $22,0 \%$ \\
\hline Total Responden & 159 & \\
\hline
\end{tabular}

Berdasarkan jenis perjalanannya, sebagian besar (80 orang; 50,3\%) responden mempergunakan angkot untuk keperluan transportasi dari dan menuju kampus. Selebihnya menggunakan angkot untuk keperluan berbelanja, rekreasi, serta berbagai keperluan lainnya.

\section{Kepuasan Terhadap Pelayanan}

Melalui wawancara dengan 159 responden mahasiswa terhadap 14 jenis kriteria pelayanan diperoleh tanggapan tingkat kepentingan dan nilai kepuasan seperti pada Tabel 2. Pada tabel ini juga ditampilkan hasil perhitungan bobot kepentingan untuk masing-masing kriteria pelayanan beserta dengan hasil perhitungan nilai kepuasan konsumen. Bobot kepentingan dihitung berdasarkan rasio antara rerata nilai kepentingan kriteria $k$ terhadap total rerata nilai kepentingan. Responden menilai kepentingan masing-masing kriteria pelayanan sebagai 
'sangat penting', terlihat dari rerata nilai kepentingan di atas angka 8,00. Sementara itu nilai kepuasan memiliki rata-rata 4,82 yang menandakan nilai yang cukup buruk.

Tabel 2. Nilai Kepuasan Berdasarkan Bobot Nilai Kepentingan

\begin{tabular}{|c|c|c|c|c|c|c|}
\hline No. & $\begin{array}{l}\text { ASPEK } \\
\text { Pelayanan }\end{array}$ & $\begin{array}{l}\text { KRITERIA } \\
\text { Pelayanan }\end{array}$ & $\begin{array}{l}\text { Rerata Nilai } \\
\text { Kepentingan }\end{array}$ & $\begin{array}{c}\text { Bobot } \\
\text { Kepentingan }\end{array}$ & $\begin{array}{c}\text { Rerata } \\
\text { Nilai } \\
\text { Kepuasan }\end{array}$ & $\begin{array}{c}\text { Nilai } \\
\text { Kepuasan } \\
\text { Menurut } \\
\text { bobot } \\
\text { kepentingan }\end{array}$ \\
\hline 1 & \multirow{2}{*}{$\begin{array}{l}\text { Karakteristik } \\
\text { Rute }\end{array}$} & $\begin{array}{l}\text { Cakupan rute } \\
\text { angkot }\end{array}$ & 8,06 & 0,068 & 5,65 & 0,386 \\
\hline 2 & & $\begin{array}{l}\text { Jarak menuju } \\
\text { lokasi angkot }\end{array}$ & 8,22 & 0,070 & 5,84 & 0,406 \\
\hline & \multirow{3}{*}{$\begin{array}{l}4 \\
\text { Keterandalan } \\
\text { Pelayanan }\end{array}$} & $\begin{array}{l}\text { Waktu menunggu } \\
\text { datangnya angkot }\end{array}$ & 8,28 & 0,070 & 5,74 & 0,402 \\
\hline 4 & & $\begin{array}{l}\text { Waktu operasi } \\
\text { angkot }\end{array}$ & 8,44 & 0,071 & 5,15 & 0,368 \\
\hline 5 & & $\begin{array}{l}\text { Keterandalan } \\
\text { waktu tempuh }\end{array}$ & 8,41 & 0,071 & 4,21 & 0,299 \\
\hline 6 & \multirow{3}{*}{ Kenyamanan } & $\begin{array}{l}\text { Kepadatan } \\
\text { penumpang }\end{array}$ & 8,48 & 0,072 & 4,39 & 0,315 \\
\hline 7 & & $\begin{array}{l}\text { Kenyamanan } \\
\text { dalam angkot }\end{array}$ & 8,60 & 0,073 & 4,74 & 0,345 \\
\hline 8 & & Tingkat kebisingan & 8,23 & 0,070 & 4,30 & 0,299 \\
\hline 9 & \multirow{2}{*}{ Kebersihan } & Kebersihan angkot & 8,65 & 0,073 & 4,61 & 0,338 \\
\hline 10 & & Tampilan luar & 7,90 & 0,067 & 4,84 & 0,324 \\
\hline 11 & Tarif & Tarif Ongkos & 8,68 & 0,073 & 5,37 & 0,394 \\
\hline 12 & \multirow[b]{2}{*}{ Pengemudi } & Perilaku supir & 8,96 & 0,076 & 3,94 & 0,299 \\
\hline 13 & & $\begin{array}{l}\text { Penampilan dan } \\
\text { kebersihan supir }\end{array}$ & 8,43 & 0,071 & 4,25 & 0,303 \\
\hline \multirow[t]{3}{*}{14} & Keamanan & Keamanan & 8,83 & 0,075 & 4,49 & 0,336 \\
\hline & & Rerata & 8,44 & \multirow{2}{*}{\multicolumn{2}{|c|}{$\begin{array}{r}4,82 \\
\text { Customer Satisfaction } \\
\text { Index : }\end{array}$}} & \\
\hline & & Total nilai & 118,17 & & & 4,81 \\
\hline
\end{tabular}

\section{Prioritas Peningkatan Kualitas Pelayanan}

Gambar 1 menunjukkan pembagian keempat kuadran berdasarkan nilai tengah skala penilaian (nilai 5). Tampak bahwa 9 kriteria penilaian berada pada kuadran 4 (diarsir). Berdasarkan hasil tersebut, kriteria pelayanan yang harus menjadi prioritas mengalami perbaikan adalah: (5)Keterandalan waktu tempuh, (6)Kepadatan penumpang, (7)Kenyamanan dalam angkot, (8)Tingkat kebisingan, (9)Kebersihan angkot, (10)Tampilan luar, (12)Perilaku supir, (13)Penampilan dan kebersihan supir, (14)Keamanan. Di sisi lain, kelima kriteria lainnya tidak menjadi prioritas paling dini, sehingga cukup diberikan pemeliharaan guna menjaga kinerjanya saat ini. Tidak ada kriteria pelayanan yang berada pada kuadran 2 dan 3 . 


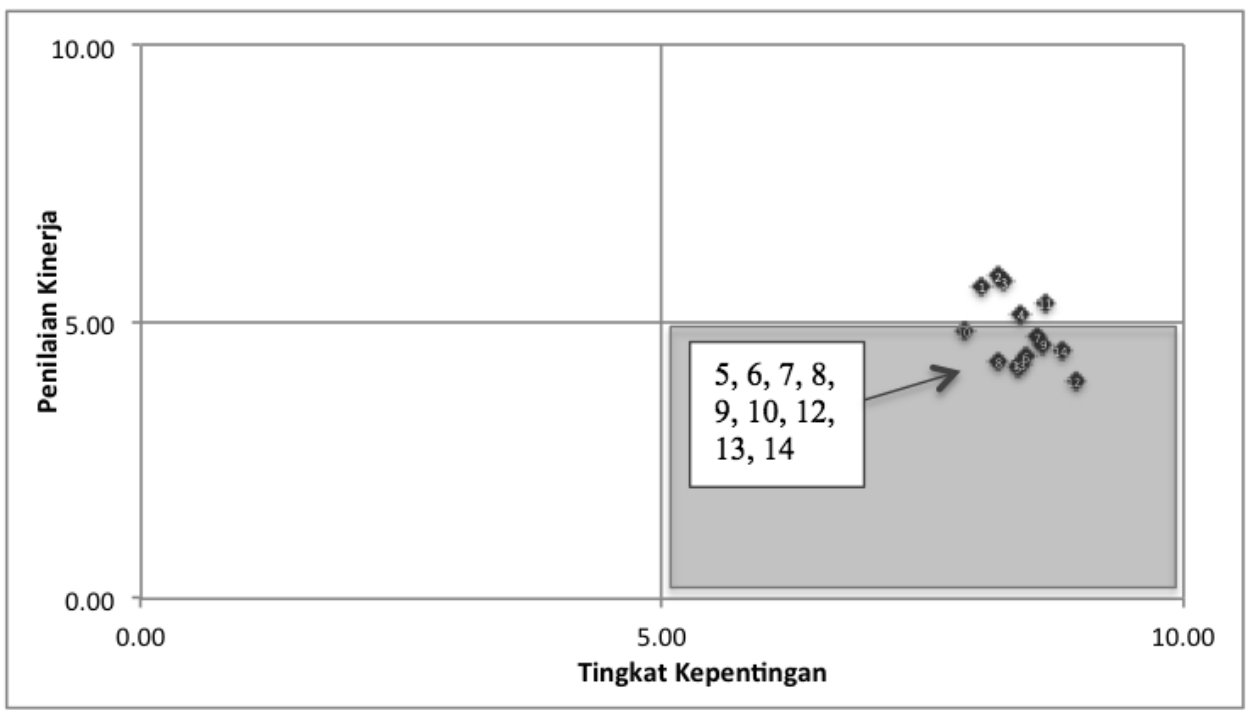

Gambar 2 Pembagian Kuadran IPA Berdasarkan Nilai Tengah Skala Penilaian

Pada Gambar 3, pembagian kuadran didasarkan pada nilai rerata kepentingan dan nilai rerata kepuasan. Pembagian kuadran dengan cara ini menjadikan plotting 14 kriteria pelayanan lebih mikroskopik.

Enam kriteria berada pada kuadran 4 (diarsir) yakni: (6)Kepadatan penumpang, (7)Kenyamanan dalam angkot, (9)Kebersihan angkot, (12)Perilaku supir, (13)Penampilan dan kebersihan supir, (14)Keamanan. Kriteria-kriteria ini dinilai sangat penting oleh responden mahasiswa, tetapi kualitas pelayanan yang diberikan oleh penyedia layanan saat ini masih buruk menurut responden tersebut. Lebih spesifik, kriteria pelayanan yang sangat membutuhkan perbaikan merupakan kriteria No. 12 (perilaku supir) karena memiliki kesesuai nilai kepuasan yang paling rendah terhadap nilai kepentingannya.

Berbeda dengan gambar untuk pembagian kuadran berdasarkan nilai tengah, dengan metoda pembagian kuadran seperti ini terdapat beberapa kriteria pada kuadran 2 dan kuadran 3.

Kuadran 2 (kualitas pelayanan cenderung melebihi keperluan):

- Cakupan rute angkot

- Jarak menuju lokasi angkot

- Waktu menunggu datangnya angkot

- Tampilan luar angkot

Kuadran 3 (prioritas pelayanan sangat rendah karena tingkat kepentingan rendah):

- Keterandalan waktu tempuh

- Tingkat kebisingan

Berdasarkan analisa ini, masukan yang dapat diberikan kepada penyedia layanan adalah untuk mengutamakan penanganan pelayanan pada kriteria pelayanan yang jatuh pada kuadran dengan arsiran (kuadran 4). Hal ini dapat meningkatkan indeks kepuasan pengguna tetapi tidak serta merta meningkatkan secara signifikan, terutama jika nilai kepentingan yang diberikan oleh respondenuntuk masing-masing kriteria pelayanan cenderung seragam. 


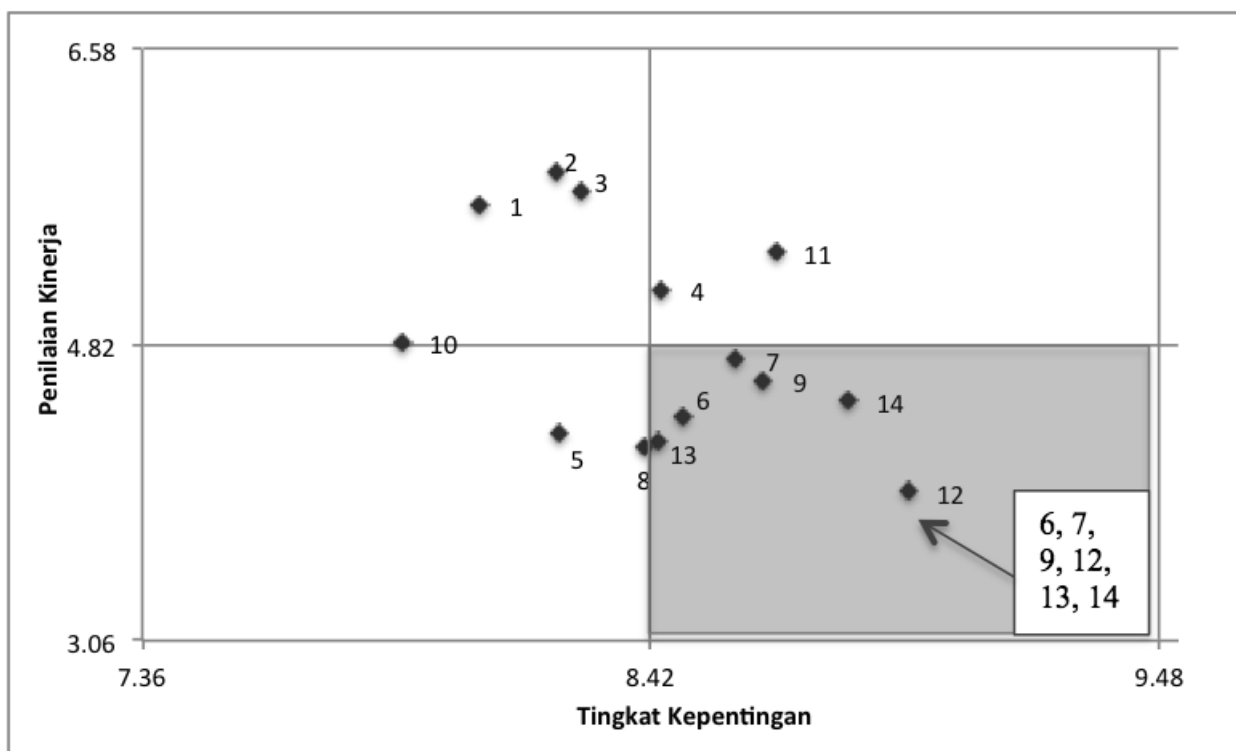

Gambar 2. Pembagian Kuadran IPA Berdasarkan Nilai Rata-Rata Kepuasan dan Nilai Rata-Rata Tingkat Kepentingan

\section{Kesimpulan}

Terdapat 14 kriteria pelayanan yang menjadi perhatian dalam penelitian ini, yaitu: Cakupan rute angkot, Jarak menuju lokasi angkot, Waktu menunggu datangnya angkot, Waktu operasi angkot, Keterandalan waktu tempuh, Kepadatan penumpang, Kenyamanan dalam angkot, Tingkat kebisingan, Kebersihan angkot, Tampilan luar, Tarif Ongkos, Perilaku supir, Penampilan dan kebersihan supir, Keamanan. Berdasarkan hasil analisa, Indeks Kepuasan Pengguna (CSI) berada di bawah nilai tengah yakni 4,81. Angka ini menunjukkan bahwa kualitas pelayanan angkot dinilai cukup buruk oleh responden mahasiswa. Waktu operasional angkot dan ongkos angkot saat ini dinilai cukup baik oleh responden mahasiswa. Di antara 14 kriteria pelayanan, terdapat 6 (enam) kriteria pelayanan yang perlu diprioritaskan untuk mengalami perbaikan. Kriteria pelayanan yang paling utama adalah 'perilaku supir'.

\section{Daftar Pustaka}

Dell'Olio, L., Ibeas, A., \& Cecin, P. (2011). The quality of service desired by public transport users. Transport Policy, 18(1), 217-227.

Eboli, L., \& Mazzulla, G. (2007). Service quality attributes affecting customer satisfaction for bus transit. Journal of public transportation, 10(3), 2.

Fellesson, M., \& Friman, M. (2012, February). Perceived satisfaction with public transport service in nine European cities. In Journal of the Transportation Research Forum (Vol. 47, No. 3).

Hayes, B. E. (1998). Measuring customer satisfaction: Survey design, use, and statistical analysis methods. ASQ Quality Press.

Idris, Z. (2009). Kajian “Tingkat Kepuasan” Pengguna Angkutan Umum di DIY. Dinamika Teknik Sipil (Vol 9, No. 2).

Martilla, J. A., \& James, J. C. (1977). Importance-performance analysis. The journal of marketing, 7779.

Parasuraman, A., Zeithaml, V. A., \& Berry, L. L. (1985). A conceptual model of service quality and its implications for future research. the Journal of Marketing, 41-50.

Randheer, K., \& Al-Motawa, A. A. (2011). Measuring commuters' perception on service quality using SERVQUAL in public transportation. International Journal of Marketing Studies, 3(1), 21.

Redman, L., Friman, M., Gärling, T., \& Hartig, T. (2013). Quality attributes of public transport that attract car users: A research review. Transport Policy, 25, 119-127. 
Setiawan, R. (2005). Analisa tingkat kepuasan pengguna kereta api komuter surabaya-sidoarjo. Simposium VIII FSTPT, Universitas Sriwijaya, 5-6.

Sever, I. (2015). Importance-performance analysis: A valid management tool?. Tourism Management, 48, 43-53.

Stradling, S. G., Anable, J., \& Carreno, M. (2007). Performance, importance and user disgruntlement: A six-step method for measuring satisfaction with travel modes. Transportation Research Part A: Policy and Practice, 41(1), 98-106.

Tyrinopoulos, Y., \& Antoniou, C. (2008). Public transit user satisfaction: Variability and policy implications. Transport Policy,15(4), 260-272. 